\title{
Pengaruh Penyuluhan Kesehatan Tentang Penggunaan Alat Pelindung Diri Terhadap Perilaku Petani Di Desa Petukel Blang Jorong Kecamataı Bandar Kabupaten Bener Meriah Tahun 2019
}

\section{Effect On The Use Of Health Counseling Protective Equipment Behavior Of Farmers In The Village Petukel District Bandar Bener Meriah Regency In 2019}

\author{
Zuidah(1)* \& Salda Yanti(2) \\ Program Studi Ilmu Keperawatan, Universitas Haji Sumatera Utara, Indonesia
}

Disubmit: 22 November 2020; Diproses: 22 November 2020; Diaccept: 29 November 2020; Dipublish: 01 Desember 2020 *Corresponding author: E-mail: zuidah@gmail.com \begin{abstract}
Abstrak
Pemakaian alat pelindung diri merupakan salah satu cara pencegahan terjadinya keracunan pestisida. Pestisida dapat masuk kedalam tubuh melalui kulit dan sistem pernapasan. Menurut WHO di seluruh dunia terajadi 4 ratus ribu- 2 juta mengalami keracunan pestisida. Tujuan penelitian ini untuk mengetahui pengaruh penyuluhan kesehatan tentang penggunaan alat pelindung diri terhadap perilaku di Desa Petukel Blang Jorong Kecamatan Bandar Kabupaten Bener Meriah Tahun 2019. Penelitian ini menggunakan desain Pra-eksperimen dengan rancangan one group pretes and posttest, populasi dalam penelitian ini adalah seluruh petani yang menggunakan pestisida sebanyak 456 orang. Teknik pengambilan sampel dengan accidental sampling, jumlah sampel sebanyak 30 orang. Instrumen yang digunakan menggunakan kuesioner dan leflet. Analisa data dilakukan dengan univariat dan bivariat menggunakan Wilcoxon signed rank test. Hasil penelitian bahwa perilaku sebelum diberikan penyuluhan kesehatan tentang penggunaan alat pelindung diri mayoritas kurang sebanyak 15 responden (50\%), perilaku sesudah diberikan penyuluhan kesehatan tentang penggunaan alat pelindung diri mayoritas baik sebanyak 21 responden (70\%). Hasil uji statistik dengan uji wilcoxon pengaruh pengaruh penyuluhan kesehatan tentang penggunaan alat pelindung diri terhadap perilaku di Desa Petukel Blang Jorong Kecamatan Bandar Kabupaten Bener Meriah Tahun 2019 dengan nilai P-value 0,000. Kesimpulan penelitian terdapat pengaruh penyuluhan kesehatan tentang penggunaan alat pelindung diri terhadap perilaku di Desa Petukel Blang Jorong Kecamatan Bandar Meriah Tahun 2019. Disarankan untuk pihak aparat desa untuk dapat memberikan informasi tentang penggunaan alat pelindung diri yang baik pada petani sehingga mengurangi terjadinya keracunan pada petani.
\end{abstract}

Kata Kunci: Penyuluh Kesehatan; Perilaku

Abstract

The use of personal protective equipment is one how to prevent pesticide poisoning. Pesticides can enter the body through the skin and respiratory system. According to WHO worldwide terajadi four hundred thousand to 2 million suffered pesticide poisoning. The purpose of this study to determine the effect of health education on the use of personal protective equipment against the behavior in the village of Blang Jorong Petukel Bener Meriah District Subdistrict Bandar 2019. The design of this study Pre-experimental design with one group pretest and posttest, the population in this study were all farmers who use pesticides as many as 456 people. The sampling technique accidental sampling, the sample size of 30 people. The instrument used a questionnaire and Leflet. Data was analyzed by univariate and bivariate using the Wilcoxon signed rank test. The results of the study that behavior before being given health education on the use of personal protective equipment majority kurang as much as 15 respondents (50\%), behavior after the given health education on the use of personal protective equipment a good majority were 21 respondents (70\%). Results of statistical test by Wilcoxon test the effect of the influence of health education on the use of personal protective equipment against the behavior in the village of Blang Jorong Petukel Bener Meriah District Subdistrict Bandar 2019 with P-value of 0.000. The conclusion there are significant health education about the use of personal protective equipment against the behavior in the village of Blang Jorong Petukel Bandar Meriah District of the Year 2019. It is recommended for the village officials to provide information about the use of personal protective equipment that is good for farmers, thereby reducing the occurrence of poisoning a farmer.

Keywords : Health Extension, Behavior

Rekomendasi mensitasi :

Zuidah., \& Yanti, S., 2020Pengaruh Penyuluhan Kesehata Tentang Penggunaan Alat Pelindung Diri Terhadap Perilak Petani Di Desa Petukel Blang Jorong Kecamatan Banda Kabupaten Bener Meriah Tahun 2019. Jurnal Penelitia Pendidikan, Psikologi dan Kesehatan (J-P3K), 1 (3): 260-268. 


\section{PENDAHULUAN}

Indonesia merupakan salah satu negara berkembang dan negara agraris yang sebagian penduduknya memiliki mata pencaharian sebagai petani. Petani merupakan kelompok kerja terbesar di Indonesia. Banyak wilayah kabupaten di Indonesia yang mengandalkan pertanian, termasuk perkebunan sebagai sumber penghasilan utama daerah salah satunya kabupaten Bener Meriah. Berdasarkan pekerjaannya sebagian besar adalah petani yang dapat bertahan hidup dari hasil pertanian yang dikelola semasa hidupnya (Achmadi, 2008).

Apabila hasil pertaniannya diserang oleh hama, maka dapat menurunkan hasil pertanian dan bahkan petani sama sekali tidak dapat menikmati hasil pertaniannya itu sendiri. Oleh karena itu petani menggunakan bahan kimia sebagai penolong dalam bidang pertanian untuk mempertahankan hasil pertaniannya demi memperpanjang kelangsungan hidupnya. Adapun bahan kimia yang sering digunakan oleh petani biasanya disebut dengan Pestisida (Yudiarti, 2007).

Menurut World Health Organization (WHO), di seluruh dunia diperkirakan per tahunnya terjadi 4 ratus ribu sampai 2 juta orang mengalami keracunan pestisida yang menyebabkan kematian antara 10.000-40.000 orang. Keracunan yang sangat tragis terjadi di Irak pada petani melarat. yang telah diperlakukan dengan fungsida ptoluen sulfonanilida dan tercemarnya perairan oleh fungsida tersebut diperkirakan 5.000-50.000 orang telah meninggal dunia lebih dari 100.000 orang atau bahkan mungkin sampai 500.000 orang menjadi cacat seumur hidup. Menurut Setiono, di Indonesia diperkirakan terjadi 300.000 kasus keracunan setiap tahunnya, walaupun hanya sebagian kecil yang bersifat fatal (Khamdani, 2009).

Dalam bidang pertanian menyemprot pestisida merupakan suatu keharusan dan sarana untuk membunuh hama-hama tanaman (Isnaini, 2006).

Beberapa kasus keracunan pestisida yang terjadi di Indonesia, antara lain di Kulon Progo terdapat 210 kasus keracunan dengan pemeriksaan fisik dan klinis, 50 orang di antaranya diperiksa di laboratorium dengan hasil 15 orang (30\%) positif keracunan. Daerah Kabupaten Sleman dilaporkan dari 30 orang petugas pemberantas hama 14 orang $(46,66 \%)$ mengalami gejala keracunan serta di Bali. Berdasarkan data pemeriksaan aktivitas cholinesterase yang dilakukan UPT Balai Higiene Perusahaan Ergonomi dan Kesehatan (Hiperkes) dan Kartu Keluarga (KK) Provinsi Bali pada tahun 2013, prevalensi petani di Bali yang mengalami keracunan pestisida sebesar 41\%. Petani tanaman hortikultura sangat berisiko mengalami keracunan pestisida dengan dampak negatif jangka panjang. Efek negatif dari pajanan pestisida jangka panjang dapat menimbulkan berbagai gangguan kesehatan yang salah satunya gangguan sistem saraf (gangguan keseimbangan tubuh). Hal ini berkaitan dengan keterlibatan petani dalam kegiatan di bidang pertanian, seperti menyemprot, menyiapkan perlengkapan untuk menyemprot, mencampur pestisida, mencuci peralatan/pakaian yang dipakai saat menyemprot (Khamdani, 2009).

Hasil penelitian Defrianto (Putra, 2014) menunjukkan bahwa sebelum penyuluhan, lebih dari 20 petani $(>65 \%)$ 
memiliki pengetahuan dan sikap yang kurang. Setelah penyuluhan, pengetahuan dan sikap petani menjadi baik 100\%. Dari uji statistic Wilcoxon baik pada pengetahuan maupun sikap diperoleh $\mathrm{P}$ value sebesar 0,000. Artinya pada alpha $5 \%$ terdapat perbedaan yang signifikan pada skor median antara sebelum dan setelah penyuluhan. Sedangkan pada aspek tindakan, terjadi peningkatan jumlah penggunaan APD antara sebelum dan sesudah penyuluhan.

Menurut Azwar (Maulana, 2009), penyuluhan kesehatan diartikan sebagai kegiatan pendidikan kesehatan yang dilakukan dengan cara menyebarluaskan pesan dan menanamkan keyakinan.

APD merupakan alat yang digunakan oleh para pekerja untuk melindungi diri dari bahaya yang ditimbulkan di tempat kerja1. Bidang pertanian sebagai pengguna pestisida paling banyak, di Indonesia jumlah pestisida yang terdaftar semakin meningkat yaitu sebanyak 166 jenis (Tahun 2006) meningkat menjadi 2628 (Tahun 2010).

Berdasarkan survey awal yang dilakukan peneliti pada bulan November 2018 di desa Blang Jorong Kecamatan Bandar Kabupaten Bener meriah Provinsi Aceh, Dari 82 petani peniliti mendapatkan 20 petani diantaranya 6 orang mengerti dan 14 orang tidak mengerti tentang APD Peneliti ingin mengambil penelitian ini.

Berdasarkan hasil survey awal, Peneliti tertarik melakukan penelitian yang berjudul "Pengaruh Penyuluhan Kesehatan Tentang Penggunaan APD Terhadap Perubahan Perilaku Petani di Desa Petukel Blang Jorong Kecamatan
Bandar Kabupaten Bener Meriah Tahun 2019".

\section{METODE PENELITIAN}

Penelitian ini menggunakan desain Pra-eksperimen dengan rancangan one group pretes and posttest, populasi dalam penelitian ini adalah seluruh petani yang menggunakan pestisida sebanyak 456 orang. Teknik pengambilan sampel dengan accidental sampling, jumlah sampel sebanyak 30 orang. Instrumen yang digunakan menggunakan kuesioner dan leflet. Analisa data dilakukan dengan univariat dan bivariat menggunakan Wilcoxon signed rank test.

\section{HASIL DAN PEMBAHASAN}

Pengetahuan Sebelum dan Sesudah Dilakukan Penyuluhan Kesehatan Tentang Penggunaan Alat Pelindung Diri Pada Petani Di Desa Petukel Blang Jorong Kecamatan Bandar Kabupaten Bener Meriah Tahun 2019

Tabel 1. Pengetahuan Sebelum dan Sesudah Penyuluhan

\begin{tabular}{llllll}
\hline No & $\begin{array}{l}\text { Pengetahu } \\
\text { an }\end{array}$ & F & $\%$ & Mean & $\begin{array}{l}\text { Std } \\
\text { Deviasi }\end{array}$ \\
\hline & Sebelum & & & & \\
1. & Baik & 2 & 6,7 & & \\
2. & Cukup & 15 & 50 & 4,93 & 1,413 \\
3. & Kurang & 13 & 43,3 & & \\
\hline & Total & 30 & 100 & & \\
\hline & Sesudah & & & & \\
1 & Baik & 22 & 73,4 & & \\
2 & Cukup & 7 & 23,3 & 7,70 & 1,601 \\
3 & Kurang & 1 & 3,3 & & \\
\hline & Total & 30 & 100 & & \\
\hline
\end{tabular}

Berdasarkan tabel 1 diketahui bahwa dari hasil sebelum penyuluhan kesehatan tentang penggunaan alat pelindung diri mayoritas memiliki pengetahuan yang cukup sebanyak 15 responden (50\%) dan 
sesudah mayoritas memiliki pengetahuan yang baik sebanyak 22 responden (73,4\%).

Pengaruh Penyuluhan Kesehatan Tentang Penggunaan Alat Pelindung Diri Terhadap pengetahun Petani Di Desa Petukel Blang Jorong Kecamatan Bandar Kabupaten Bener Meriah Tahun 2019.

Tabel 2. Uji Wilcoxon

\begin{tabular}{cccccc}
\hline $\mathrm{N}$ & $\begin{array}{c}\text { Mean } \\
\text { Pretest }\end{array}$ & $\begin{array}{c}\text { Mean } \\
\text { Postest }\end{array}$ & Selisih & $\mathrm{Z}$ & $\mathrm{P}$ \\
\hline 30 & 4,93 & 7,70 & $-2,77$ & $-4.474^{\mathrm{a}}$ & .000 \\
\hline
\end{tabular}

Berdasarkan tabel 2 diketahui Hasil Uji Wilcoxon didapatkan niai Z sebesar 4.474 a dengan $\mathrm{p}=0,000<0,05$ sehingga Ho ditolak dan Ha diterima yang berarti ada terdapat perbedaan bermakna antara kelompok pretest dan post test.

Sikap Sebelum dan Sesudah Dilakukan Penyuluhan Kesehatan Tentang Penggunaan Alat Pelindung Diri Pada Petani Di Desa Petukel Blang Jorong Kecamatan Bandar Kabupaten Bener Meriah Tahun 2019.

Tabel 3. Hasil Penyuluhan

\begin{tabular}{|c|c|c|c|c|c|}
\hline No & Sikap & $\mathrm{F}$ & $\%$ & Mean & $\begin{array}{c}\text { Std } \\
\text { Deviasi }\end{array}$ \\
\hline & Sebelum & & & & \\
\hline 1. & Baik & 3 & 10 & & \\
\hline 2. & Cukup & 12 & 40 & 4,83 & 1,642 \\
\hline \multirow[t]{3}{*}{3.} & Kurang & 15 & 50 & & \\
\hline & Total & 30 & 100 & & \\
\hline & Sesudah & & & & \\
\hline 1. & Baik & 23 & 76,7 & & \\
\hline 2. & Cukup & 7 & 23,3 & 8,03 & 0,765 \\
\hline \multirow[t]{2}{*}{3.} & Kurang & 0 & 0 & & \\
\hline & Total & 30 & 100 & & \\
\hline
\end{tabular}

Berdasarkan tabel diatas diketahui bahwa dari hasil sebelum penyuluhan kesehatan tentang penggunaan alat pelindung diri mayoritas memiliki sikap yang kurang sebanyak 15 responden
(50\%) dan sesudah mayoritas memiliki sikap yang baik sebanyak 23 responden (76,7\%).

Pengaruh Penyuluhan Kesehatan Tentang Penggunaan Alat Pelindung Diri Terhadap Sikap Petani Di Desa Petukel Blang Jorong Kecamatan Bandar Kabupaten Bener Meriah Tahun 2019.

Tabel 4. Uji Wilcoxon

\begin{tabular}{llllll}
\hline $\mathrm{N}$ & $\begin{array}{l}\text { Mean } \\
\text { Pretest }\end{array}$ & $\begin{array}{l}\text { Mean } \\
\text { Postest }\end{array}$ & Selisih & $\mathrm{Z}$ & $\mathrm{P}$ \\
\hline 30 & 4,83 & 8,03 & $-3,02$ & $-4.846^{\mathrm{a}}$ & .000 \\
\hline
\end{tabular}

Berdasarkan tabel 4 diketahui Hasil Uji Wilcoxon didapatkan niai Z sebesar 4.486 ${ }^{\mathrm{a}}$ dengan $\mathrm{p}=0,000<0,05$ sehingga Ho ditolak dan Ha diterima yang berarti terdapat perbedaan bermakna antara kelompok pretest dan post test.

Tindakan Sebelum dan Sesudah Dilakukan Penyuluhan Kesehatan Tentang Penggunaan Alat Pelindung Diri Pada Petani Di Desa Petukel Blang Jorong Kecamatan Bandar Kabupaten Bener Meriah Tahun 2019.

Tabel 5. Uji Wilcoxon

\begin{tabular}{|c|c|c|c|c|c|}
\hline No & Tindakan & $\mathrm{F}$ & $\%$ & Mean & $\begin{array}{l}\text { Std } \\
\text { Deviasi }\end{array}$ \\
\hline & Sebelum & & & & \\
\hline 1. & Baik & 3 & 10 & & \\
\hline 2. & Cukup & 12 & 40 & 4,87 & 1,592 \\
\hline \multirow[t]{3}{*}{3.} & Kurang & 15 & 50 & & \\
\hline & Total & 30 & 100 & & \\
\hline & Sesudah & & & & \\
\hline 1. & Baik & 21 & 70 & & \\
\hline 2. & Cukup & 7 & 23,3 & 7,70 & 1,368 \\
\hline \multirow[t]{2}{*}{3.} & Kurang & 2 & 6,7 & & \\
\hline & Total & 30 & 100 & & \\
\hline
\end{tabular}

Berdasarkan tabel 5 diketahui bahwa dari hasil sebelum penyuluhan kesehatan tentang penggunaan alat pelindung diri mayoritas memiliki tindakan yang kurang sebanyak 15 responden (50\%) dan 
sesudah mayoritas memiliki tindakan baik sebanyak 21 responden (70\%).

Pengaruh Penyuluhan Kesehatan Tentang Penggunaan Alat Pelindung Diri Terhadap Tindakan Petani Di Desa Petukel Blang Jorong Kecamatan Bandar Kabupaten Bener Meriah Tahun 2019.

Tabel 6. Uji Wilcoxon

\begin{tabular}{lllllll}
\hline N & $\begin{array}{l}\text { Mean } \\
\text { Pretest }\end{array}$ & $\begin{array}{l}\text { Mean } \\
\text { Postest }\end{array}$ & Selisih & Z & P & Rank \\
\hline 30 & 4,87 & 7,70 & $-2,83$ & $-4.828 \mathrm{a}$ & .000 & 30 \\
\hline
\end{tabular}

Berdasarkan tabel 6 diketahui Hasil Uji Wilcoxon didapatkan niai Z sebesar 4.828 a dengan $\mathrm{p}=0,000<0,05$ sehingga Ho ditolak dan Ha diterima yang berarti terdapat perbedaan bermakna antara kelompok pretest dan post test.

Pengetahuan petani sebelum dan sesudah diberikan penyuluhan kesehatan tentang penggunaan alat pelindung diri di Desa Petukel Blang Jorong Kecamatan Bandar Kabupaten Bener Meriah Tahun 2019

Berdasarkan hasil penelitian diatas diperoleh bahwa pengetahuan petani sebelum dan sesudah diberikan penyuluhan kesehatan tentang penggunaan alat pelindung diri di Desa Petukel Blang Jorong Kecamatan Bandar Kabupaten Bener Meriah Tahun 2019 mayoritas kurang.

Pengetahuan adalah hasil "tahu" dan ini terjadi setelah orang megadakan penginderaan terhadap suatu objek tertentu. Penginderaan terhadap objek terjadi melalui panca indra manusia yakni penglihatan, pendengaran, penciuman, rasa dan raba dengan sendiri. Pada waktu penginderaan sampai menghasilkan pengetahuan tersebut sangat dipengaruhi oleh intensitas perhatian persepsi terhadap objek. Sebagian besar pengetahuan manusia diperoleh melalui mata dan telinga (Notoatmodjo, 2012).

Hasil penelitian ini berdasarkan analisa univariat diperoleh bahwa pengetahuan sebelum diberikan penyuluhan kesehatan tentang penggunaan alat pelindung diri terhadap perubahan perilaku petani mayoritas cukup sebanyak 15 orang. Hal ini bisa terjadi karena latar belakang tingkat pendidikan petani yang berbeda, dimana pendidikan responden mayoritas SMA 11 orang.

Salah satu faktor yang mempengaruhi pengetahuan responden adalah tingkat pendidikan terakhir, hal ini didukung Dalam penelitian Cannonier (Fitriana, 2019) ditemukan bahwa semakin tinggi pendidikan seseorang semakin tinggi pula pengetahuan tentang kesehatan yang dimiliki, namun hal tersebut tidak berlaku pada tingkat pendidikan SMA kebawah. Tingkat pengetahuan kesehatan yang baik dimiliki oleh seseorang yang telah menginjak jenjang pendidikan terakhir perguruan tinggi.

Berdasarkan teori diatas bila dikaitkan dengan hasil penelitian ini, maka peneliti berasumsi bahwa pengetahuan petani sebelum dan sesudah diberikan penyuluhan kesehatan tentang penggunaan alat pelindung diri mayoritas baik. Hal ini dapat dikarenakan karena faktor yaitu faktor fisik dan kognitif, tingkat perkembangan, kesehatan fisik, dan proses belajar intelektual dan didukung oleh penggunaan media leaflet, isi leaflet sesuai dengan materi penyuluhan yang disampaikan dengan gambar dan warna serta menyajikan 
seluruh poin-poin materi pada leaflet di dalam kuesioner.

Pengaruh penyuluhan kesehatan tentang tentang penggunaan alat pelindung diri terhadap sikap petani di Desa Petukel Blang Jorong Kecamatan Bandar Kabupaten Bener Meriah Tahun 2019

Berdasarkan hasil penelitian diatas diperoleh bahwa diketahui Hasil Uji Wilcoxon didapatkan niai $\mathrm{Z}$ sebesar 4.474a dengan $\mathrm{p}=0,000<0,05$ sehingga Ho ditolak dan Ha diterima yang berarti terdapat perbedaan bermakna antara kelompok pretest dan post test. di peroleh nilai p-value sebesar 0,000 sehingga pvalue $(0,000<0,05)$ maka ho di tolak dan ha di terima sehingga dapat di katakan ada pengaruh penyuluhan kesehatan tentang penggunaan alat pelindung diri terhadap perubahan perilaku petani di Desa Petukel Blang Jorong Kecamatan Bandar Kabupaten Bener Meriah Tahun 2019

Pengaruh tersebut dibuktikan dengan adanya perbedaan skor rata-rata tingkat pengetahuan sesudah dan sebelum intervensi pendidikan kesehatan yang dibuktikan dengan nilai $\mathrm{P}=0,000$ dan adanya selisih rata-rata sebesar $-2,77$ hal tersebut selaras dengan hasil dalam penelitian Awouda (Minaka, Sawitri, \& Wirawan, 2016) bahwa pendidikan kesehatan sangat berpengaruh meningkatkan tingkat pengetahuan, dan pendidikan kesehatan merupakan program yang bisa diimplementasikan untuk segala usia, laki-laki maupun perempuan serta seluruh jenjang pendidikan terakhir

Sikap petani sebelum dan sesudah diberikan penyuluhan kesehatan tentang penggunaan alat pelindung diri di Desa Petukel Blang Jorong Kecamatan Bandar Kabupaten Bener Meriah Tahun 2019

Berdasarkan hasil penelitian diatas diperoleh bahwa sikap petani sebelum dan sesudah diberikan penyuluhan kesehatan tentang penggunaan alat pelindung diri di Desa Petukel Blang Jorong Kecamatan Bandar Kabupaten Bener Meriah Tahun 2019 mayoritas baik

Hal ini sesuai pernyataan Rogers dalam buku Efendi (2009), mengatakan bahwa sikap merupakan reaksi atau respon tertutup seseorang terhadap stimulus atau objek dan sikap belum dikatakan suatu tindakan ataupun aktivitas sehari-hari, tetapi predisposisi tindakan suatu perilaku. Untuk mewujudkan sikap menjadi suatu perbuatan nyata maka perlu faktor pendukung seprti fasilitas, dukungan (support) dari orang berada sekitarnya.

Berdasarkan teori di atas bila dikaitkan dengan hasil penelitian ini, maka peneliti berasumsi bahwa sikap petani sebelum dan sesudah diberikan penyuluhan kesehatan tentang penggunaan alat pelindung diri mayoritas kurang. Hal ini dapat dikarenakan faktor yang mempengaruhi sikap adalah pengetahuan jika pengetahuanya kurang maka sikapnya juga kurang. Berdasarkan penjelasan diatas peneliti berasumsi bahwa terdapat pengaruh pendidikan kesehatan terhadap sikap petani tentang penggunaan alat pelindung diri $\mathrm{Hal}$ ini didukung oleh penggunaan media leaflet, isi leaflet sesuai dengan materi penyuluhan yang disampaikan dengan gambar dan warna serta menyajikan seluruh poin-poin materi pada leaflet di dalam kuesioner. 
Pengaruh penyuluhan kesehatan tentang penggunaan alat pelindung diri terhadap sikap petani di Desa Petukel Blang Jorong Kecamatan Bandar Kabupaten Bener Meriah Tahun 2019

Berdasarkan hasil penelitian diatas diperoleh bahwa diketahui Hasil Uji Wilcoxon didapatkan niai $\mathrm{Z}$ sebesar 4.846 a dengan $\mathrm{p}=0,000<0,05$ sehingga Ho ditolak dan Ha diterima yang berarti terdapat perbedaan bermakna antara kelompok pretest dan post test. di peroleh nilai $p$-value sebesar 0,000 sehingga $p$ value $(0,000<0,05)$ maka ho di tolak dan ha di terima sehingga dapat di katakan ada pengaruh penyuluhan kesehatan tentang penggunaan alat pelindung diri terhadap sikap petani di Desa Petukel Blang Jorong Kecamatan Bandar Kabupaten Bener Meriah Tahun 2019

Pengaruh tersebut dibuktikan dengan adanya perbedaan skor rata-rata tingkat pengetahuan sesudah dan sebelum intervensi pendidikan kesehatan yang dibuktikan dengan nilai $\mathrm{P}=0,000$ dan adanya selisih rata-rata sebesar $-3,02$ hal tersebut selaras dengan hasil dalam penelitian Awouda (Minaka, Sawitri, \& Wirawan, 2016) bahwa pendidikan kesehatan berpengaruh meningkatkan tingkat pengetahuan, dan pendidikan kesehatan merupakan program yang bisa diimplementasikan untuk segala usia, lakilaki maupun perempuan, serta seluruh jenjang pendidikan terakhir.

Tindakan petani sebelum dan sesudah diberikan penyuluhan kesehatan tentang penggunaan alat pelindung diri di Desa Petukel Blang Jorong Kecamatan Bandar Kabupaten Bener Meriah Tahun 2019.
Berdasarkan hasil penelitian diatas diperoleh bahwa tindakan petani sebelum diberikan penyuluhan kesehatan tentang penggunaan alat pelindung diri di Desa Petukel Blang Jorong Kecamatan Bandar Kabupaten Bener Meriah Tahun 2019 mayoritas kurang.

Hal ini didapatkan karena pengetahuan dan sikap responden sebelum diberikan penyuluhan kesehatan mayoritas juga kurang. Hal ini didukung oleh pendapat Lewin (1970) dalam Notoatmodjo (2012) yang menyatakan bahwa faktor pembentuk perilaku akan sangat kuat jika terdapat faktor pendorong (cues) dalam diri dan lingkungan yang ditempati. Dalam penelitian ini, faktor pendorong dapat dilihat dari pendidikan responden yang mayoritas SMA. Pendidikan sangat erat kaitannya dengan pengetahuan, namun jika pendidikan yang diambil tidak menjurus pada jurusan, maka perilaku kesehatanpun akan menurun. Seseorang dengan pendidikan tinggi belum tentu mengetahui dengan detail tentang penggunaan alat pelindung diri, sehingga perilaku terhadap penggunaan alat pelindung diri pada petani cenderung kurang. Hal inilah yang menyebabkan pendidikan tidak selalu berhubungan dengan perilaku kesehatan.

Berdasarkan penjelasan di atas bila dikaitkan dengan hasil penelitian ini, maka peneliti berasumsi bahwa tindakan petani sebelum diberikan penyuluhan kesehatan tentang penggunaan alat pelindung diri mayoritas kurang. Hal ini dapat dikarenakan karena faktor yang mempengaruhi tindakan adalah pengetahuan dan sikap. jika pengetahuan 
dan sikapnya kurang maka tindakan atau perilakunya juga kurang.

Berdasarkan penjelasan diatas peneliti berasumsi bahwa terdapat pengaruh pendidikan kesehatan terhadap tindakan petani tentang penggunaan alat pelindung diri Hal ini didapatkan karena pengetahuan, sikapnya setelah diberikan penyuluhan semakin baik, karena hal yang mempengaruhi tindakan adalah pengetahuan dan sikap, juga didukung oleh penggunaan media leaflet, isi leaflet sesuai dengan materi penyuluhan yang disampaikan dengan gambar dan warna serta menyajikan seluruh poin-poin materi pada leaflet di dalam kuesioner.

Pengaruh penyuluhan kesehatan tentang tentang penggunaan alat pelindung diri terhadap tindakan petani di Desa Petukel Blang Jorong Kecamatan Bandar Kabupaten Bener Meriah Tahun 2019

Berdasarkan hasil penelitian diatas diperoleh bahwa diketahui Hasil Uji Wilcoxon didapatkan niai $\mathrm{Z}$ sebesar 4.828 ${ }^{\mathrm{a}}$ dengan $\mathrm{p}=0,000<0,05$ sehingga Ho ditolak dan Ha diterima yang berarti terdapat perbedaan bermakna antara kelompok pretest dan post test. di peroleh nilai $p$-value sebesar 0,000 sehingga $p$ value $(0,000<0,05)$ maka ho di tolak dan ha di terima sehingga dapat di katakan ada pengaruh penyuluhan kesehatan tentang penggunaan alat pelindung diri terhadap tindakan petani di Desa Petukel Blang Jorong Kecamatan Bandar Kabupaten Bener Meriah Tahun 2019.

Pengaruh tersebut dibuktikan dengan adanya perbedaan skor rata-rata tingkat pengetahuan sesudah dan sebelum intervensi pendidikan kesehatan yang dibuktikan dengan nilai $\mathrm{P}=0,000$ dan adanya selisih rata-rata sebesar $-2,83$ hal tersebut selaras dengan hasil dalam penelitian Awouda (Minaka, Sawitri, \& Wirawan, 2016) bahwa pendidikan kesehatan berpengaruh meningkatkan tingkat pengetahuan, dan pendidikan kesehatan merupakan program yang bisa diimplementasikan untuk segala usia, lakilaki maupun perempuan, serta seluruh jenjang pendidikan terakhir.

\section{SIMPULAN}

Kesimpulan penelitian terdapat pengaruh penyuluhan kesehatan tentang penggunaan alat pelindung diri terhadap perilaku di Desa Petukel Blang Jorong Kecamatan Bandar Meriah Tahun 2019. Disarankan untuk pihak aparat desa untuk dapat memberikan informasi tentang penggunaan alat pelindung diri yang baik pada petani sehingga mengurangi terjadinya keracunan pada petani.

\section{DAFTAR PUSTAKA}

Achmadi, U. F. (2008). Manajemen Penyakit Berbasis Wilayah. Jakarta: UI Press.

Afiyanti, Y. (2008). Focus Group Discussion sebagai Metode Pengumpulan Data Penelitian Kualitatif. Jurnal Keperawatan Indonesia .

Efendi. (2009). Manajemen Pusat Kesehatan Masyarakat. Jakarta: Salemba Medika.

Fitriana, F. E. (2019). Pengaruh Peer Teaching Terhadap Pengetahuan Diabetes Melitus di Wilayah Kerja Puskesmas Dlingo Bantul Yogyakarta. Yogyakarta: Fakultas Ilmu Kesehatan Universitas As 'Aisyiyah.

Isnaini, M. (2006). Pertanian Organik. Cetakan Pertama. Yogyakarta: Penerbit Kreasi Wacana.

Khamdani, F. (2009). Hubungan Antara Pengetahuan dan Sikap dengan Pemakaian Alat Pelindung Diri Pestisida Semprot pada Petani di Desa Angkatan Kidul Pati. Semarang: Fakultas Ilmu Keolahragaan Universitas Negeri Semarang.

Maulana, H. (2009). Promosi Kesehatan. Jakarta: PT Penerbit Buku Kedokteran EGC. 
Minaka, D. A., Sawitri, A. A., \& Wirawan, D. N. (2016). Hubungan Penggunaan Pestisida dan Alat Pelindung Diri dengan Keluhan Kesehatan pada Petani Holtikultura di Buleleng, Bali. Public Health and Preventive Medicine Archieve .

Notoatmodjo, S. (2012). Promosi Kesehatan dan Perilaku Kesehatan. Jakarta: PT Rineka Cipta.

Putra, D. A. (2014). Perubahan Struktur Morfologi dan Gambaran Mikroanatomi Insang Ikan Lele Akibat Paparan Limbah Cair Pewarna Batik. Semarang: Fakultas Matematika dan Ilmu Pengetahuan Alam Universitas Negeri Semarang.

Suma'mur. (2014). Higiene Perusahaan dan Keselamatan Kerja.

Triwibowo, C., \& Pusphandani, M. E. (2016). Kesehatan Lingkungan dan $\mathrm{K}_{3}$.

Wijayanti, A., Muhlisin, A., \& Listyorini, D. (2012). Hubungan Antara Tingkat Pengetahuan Tentang Bahaya Pestisida Dengan Kebiasaan Petani Menggunakan Alat Pelindung Diri (APD) Ketika Menyemprot Padi di Desa Laban Kecamatan Mojo Laban.

Wismaningsih, E. R., \& Oktaviasari, D. I. (2015). Faktor yang Berhubungan dengan Penggunaan Alat Pelingdung Diri (APD) pada Petani Penyemprot di Kecamatan Ngantru, Kabupaten Tulung Agung. Jurnal Wiyata .

Yudiarti, T. (2007). Ilmu Penyakit Tumbuhan. Edisi Pertama. Yogyakarta: Graha Ilmu. 